\title{
Antineutrophil Cytoplasmic Antibody
}

National Cancer Institute

\section{Source}

National Cancer Institute. Antineutrophil Cytoplasmic Antibody. NCI Thesaurus. Code C129400.

An autoantibody that recognizes antigens found in the cytoplasm of neutrophils. 